\title{
Lectura de Los pasajeros del viento desde una perspectiva feminista
}

\author{
Argelio García
}

Argelio García es biólogo, ha escrito artículos sobre cómic en El diario de Avisos de Tenerife, Tebeolandia y CuCo, Cuadernos de Cómic. Desde 1983 es miembro del jurado de los Premios de la Historieta de El Diario de Avisos.

Fecha de recepción: 23 de abril de 2016

Fecha de aceptación definitiva: 27 de mayo de 2016 


\title{
Resumen
}

En las sociedades surgidas después del paleolítico nunca ha existido una paridad de género. En el siglo Xvin la ley favorecía aún al hombre pero es en los Salones donde la mujer, a través de la elocuencia, comienza su carrera hacia la igual de género que culmina con el movimiento feminista. En este artículo se analiza la obra Los pasajeros del viento, de François Bourgeon desde una perspectiva feminista mediante dos personajes: Isa de Marnaye y Mary Hereford. Ellas son un ejemplo de que en todas las épocas han existido mujeres que conquistaron cotas de libertad impensables para muchas de sus contemporáneas.

Palabras claves: Los pasajeros del viento, François Bourgeon, feminismo, cómic, siglo XvıII.

\begin{abstract}
There has never been gender parity in societies developed after the Palaeolithic Era. In the eighteenth century laws favoured men but it was in the salons where women, through their eloquence, began their course to gender equality; it will later culminate in feminism. In this article we analyse the work of François Bourgeon and his comic book, Passengers of the Wind, from a feminist perspective through two characters: Isa de Marnaye and Mary Hereford. They exemplify how women of all ages have conquered levels of unthinkable freedom for many of their contemporaries.
\end{abstract}

Keywords: Passengers of the wind, François Bourgeon, feminist, comic, eighteenth century.

\section{Cita bibliográfica}

García, A. «Lectura de Los pasajeros del viento desde una perspectiva feminista», en CuCo, Cuadernos de cómic n. 8 (2017), pp 55-82. 


\section{Introducción}

La vida de la mujer del siglo xviII estaba pautada por una serie de normas sociales que dejaban un escaso margen para desarrollarse y evolucionar como persona. Se esperaba de ella que fuera la fiel imagen que la sociedad ha construido a través de un sistema patriarcal y cuya medida se establece a partir de un patrón: la moral.

Para reflejar y perpetuar la moral en un grupo social es necesario que esta se asuma como propia o que se imponga mediante leyes que controlen posibles desvaríos de sus integrantes, cuyo incumplimiento conlleve sanciones o restricciones de libertad.

En el siglo xvin, la ley favorece al hombre a expensas de la mujer. [La ley] parece tener varios fines: la protección de la sociedad contra la participación de la mujer en la vida pública; la dependencia de la mujer, cuerpo y bienes, a su marido [...] la protección de la mujer contra sí misma, es decir, contra su temperamento irreflexivo y apasionado, y el desconocimiento de sus propios intereses. La letra de la ley es la siguiente: «el marido tiene plenos poderes sobre su mujer y sobre los bienes de su mujer. Él tiene el derecho de exigir todos los deberes de sumisión que le son debidos a un ser superior». ${ }^{1}$

Ante un marco legal de estas características, los personajes femeninos de la obra Los pasajeros del viento, ${ }^{2}$ de François Bourgeon, deberían ser solo marionetas en manos de sus compañeros masculinos; la dependencia social y económica de la mujer las obligaría a ser honorables en la vida pública; y, como el honor se mide por el grado de cumplimiento de las leyes morales, la sumisión sería su única alternativa. Sin embargo, en todas las épocas han existido mujeres que lograron mayor libertad e independencia que las otorgadas por las leyes: ellas vivían fuera de su tiempo. ${ }^{3}$

${ }^{1}$ Slosmanis, B. La morale féminine dans «Delphine» et «Corinne» de Madame de Staël [tesis doctoral]. Montreal, McGill University, 1990, p. 8. Disponible en http://digitool.library.mcgill.ca/webclient/StreamGate?folder id=0\&dvs=1495973179643 456

${ }^{2}$ La obra de Los pasajeros del viento consta de siete álbumes. Los cinco primeros fueron publicados por la editorial Glénat bajo los títulos siguientes: «La fille sous la dunette» (1979); «Le ponton» (1980); «Le comptoir de Juda» (1981); «L'heure du serpent» (1982); «Le bois d’ébène» (1984). Los dos últimos tomos fueron publicados por la editorial 12bis bajo un título común: «La Petite Fille Bois-Caïman» libro 1.0 (2009) y libro 2. ${ }^{\circ}(2010)$.

3 Goncourt, E. \& Goncourt, J. La Femme au Dix-Huitième Siècle. París, G. Charpentier Éditeur, 1882, pp. 371-405. 
El presente trabajo sobre Los pasajeros del viento se centrará, especialmente, en dos de sus personajes femeninos, Isa y Mary (FIG. 1), cuya mentalidad, sin ser anacrónica, trasciende la de su época. ${ }^{4}$ Así, podríamos ver en Isa a una mujer contestataria, feminista, que no teme ni la exposición de su cuerpo ni la de su pensamiento, laica e incluso anticlerical; y en Mary a su contraria / complementaria, generosa, sensual y más instintiva que intelectual. ${ }^{5}$ Desde una óptica feminista describiremos, sucintamente, las vivencias de Isa y Mary en cuanto al modo de vida, la elocuencia, la dependencia económica, las relaciones afectivas, la seducción, la maternidad y el vestido a través del canon de la moda dieciochesca.
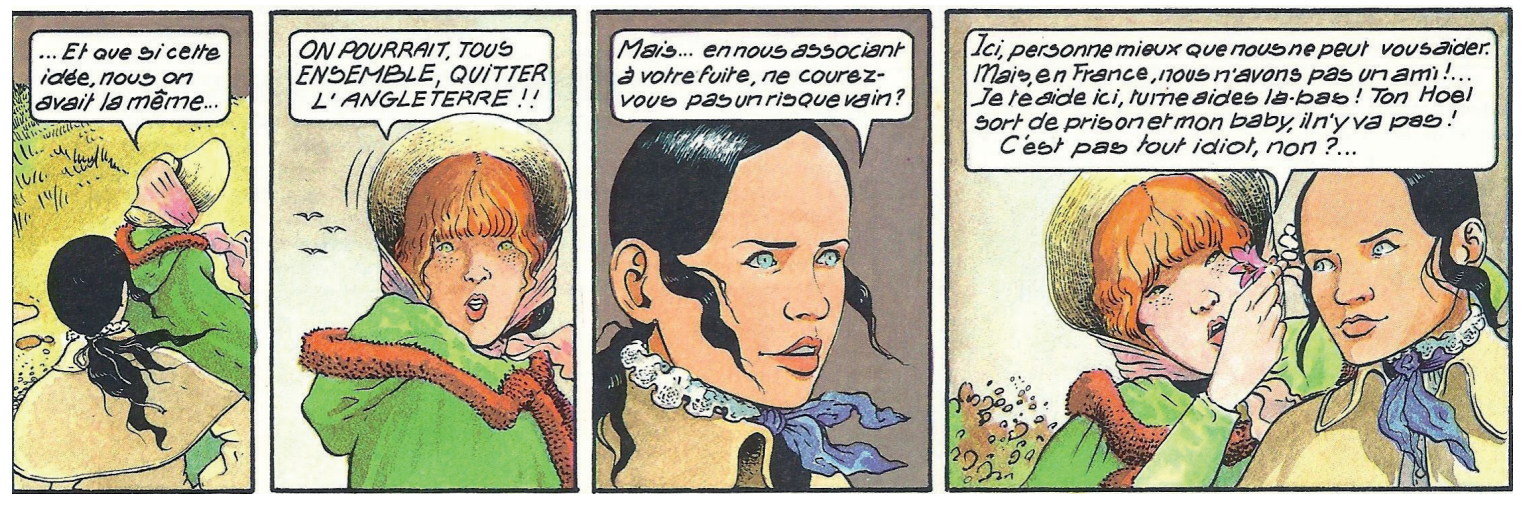

FIG. 1. Isa y Mary son los personajes femeninos de Los pasajeros del viento que buscan vivir al margen de las normas sociales que, en el siglo XVIII, se imponían a la mujer. En esta secuencia, Mary anuncia su intención de abandonar su casa y su país para lo que solicita la colaboración de Isa. («Le ponton», Glénat, 1980, p. 6).

\section{La infancia}

Isa (nacida Agnes de Roselande) procede de una familia aristocrática; su madre muere cuando ella apenas contaba tres años y su padre (Simon de Roselande) la traslada a una propiedad familiar en la campiña, para que sea educada por una gobernanta, en compañía de una niña huérfana de una familia de la pequeña nobleza: Agnes (nacida Isabeau de Marnaye).

En las familias aristocráticas del siglo XVIII, con frecuencia, se contrataba una nodriza para criar a los niños y se dejaba la educación a una gobernanta. Las niñas recibían una formación elemental que incluía la lectura, la escritura y unos conocimientos básicos de geografía. ${ }^{6}$

\footnotetext{
${ }^{4}$ Dada la amplitud de la obra Los pasajeros del viento, a efectos prácticos, solo trataremos el periodo que transcurre durante el siglo XviII.

5 Pierpont, J. «Esclavage et condition feminine», en Les Cabiers de la bande dessinée, n. ${ }^{\circ} 65$ (1985), pp. 24-25.

${ }^{6}$ Slosmanis, B. Op. cit., p. 9.
} 
Isa y Agnes vivirán seis años en la campiña hasta que muere la gobernanta. Entonces, Simon de Roselande anuncia que pasará a recoger a las niñas para ocuparse él mismo de su educación. Las niñas, que pese a no ser parientes tienen un gran parecido físico, se intercambian sus vestidos para ver si Simon de Roselande puede reconocer a su propia hija (FIG. 2). Esta broma tendrá terribles consecuencias. El padre, hombre autoritario, no deja hablar a las niñas y se lleva con él a Isabeau de Marnaye, creyendo que es su hija, convirtiéndose así en Agnes; mientras que su propia hija, Agnes de Roselande, es enviada a un convento, perdiendo su condición de aristócrata, convirtiéndose en Isa.

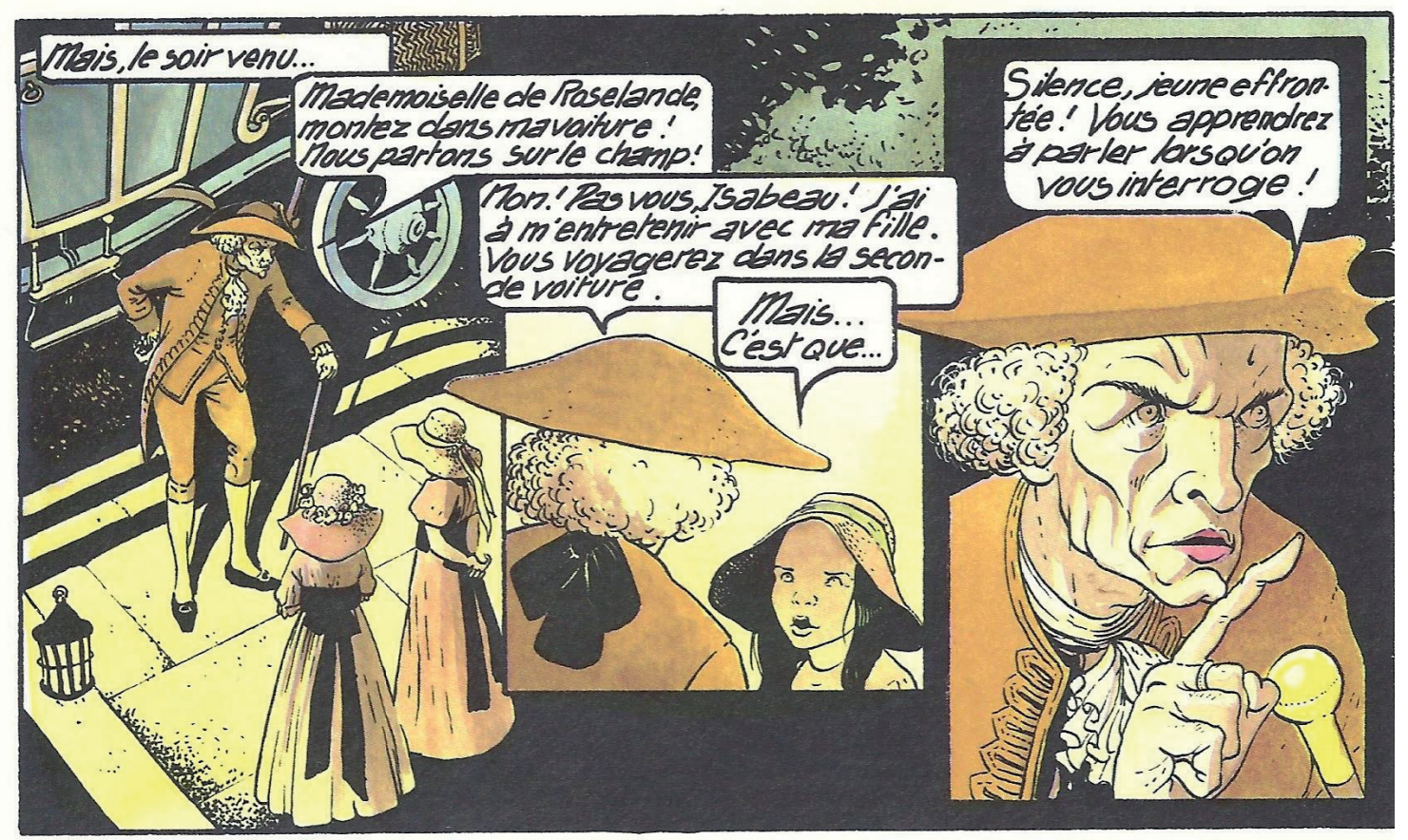

FIG. 2. Isa y Agnes intercambian sus vestidos que llevan grabados las iniciales de sus nombres. Simon de Roselande ni reconoce a su hija ni la deja hablar, por lo que acabará recluida en un convento. El vestido sirve para determinar la posición social de un individuo. («La fille sous la dunette», Glénat, 1979, p. 24).

\section{El convento}

En la Francia del siglo xvini, el convento no era una institución totalmente cerrada al mundo exterior: «las residentes [seglares] eran una representación de la sociedad [...] vivían normalmente en edificios separados del convento», ${ }^{7}$ de modo que junto a las religiosas convivían jóvenes y mujeres de distinto origen y orden social; ellas ingresaban en el convento por diferentes razones y aportaban cambios sustanciales en la austeridad de las costumbres de la orden religiosa; así «la palabra inscrita en el frontón de las Nouvelles

\footnotetext{
7 Ibid., p. 10.
} 
catholiques "vincit mundum fides nostra fe" " tan solo era letra muerta: el mundo había puesto un pie en el claustro». ${ }^{9}$

El ingreso de Isa en un convento no es un hecho infrecuente, ya que en el siglo XviII muchas jóvenes eran enviadas a esta institución para su formación hasta la edad conveniente para contraer matrimonio. Finalmente, el convento era la única institución pedagógica para las jóvenes. «Allí se enseñaba el catecismo, el clavecín, la danza y el canto. Algunas pensionistas se casaban desde los doce o trece años pero la mayor parte permanecían en el convento hasta su adolescencia». ${ }^{10}$

Isa pasará cinco años en el convento cultivando «el odio, la mentira y la hipocresía» («La fille sous la dunette», p. 25); Agnes la libera de los muros del claustro y promete hacerla feliz, pero a condición de que Isa no desvele el secreto de su verdadera identidad. Isa acepta la propuesta pero logrará hacerse imprescindible para Agnes, que se convertirá en un ser totalmente dependiente de Isa.

\section{Lesbianismo}

«[La homosexualidad] es una actitud elegida en situación, es decir, a la vez motivada y libremente adoptada». ${ }^{11}$ Esta frase de Simone de Beauvoir ayuda a comprender la elección de la homosexualidad por parte de Isa durante su adolescencia («La fille sous la dunette»). La motivación era controlar emocionalmente a Agnes para evitar un nuevo internamiento en el convento; pudo explorar otras opciones, pero libremente adoptó la homosexualidad porque parece que la convivencia en el convento le aportó cierta experiencia en esta forma de vivir la sexualidad («La fille sous la dunette», p. 26). Además, «si se evoca a la naturaleza, podemos decir que naturalmente toda mujer es homosexual». ${ }^{12}$

En el libro solo hay una escena en la que se muestre explícitamente la relación lésbica entre Agnes e Isa («La fille sous la dunette», p. 20); esta nos hace evocar un hermoso texto de Simone de Beauvoir:

El amor es contemplación; las caricias se realizan no para apropiarse de la otra sino para recrearse lentamente a través de ella; la separación está abolida, no hay lucha, ni victoria, ni derrota; en una exacta reciprocidad cada una es a la vez sujeto y objeto, la soberana y la esclava; la dualidad es complicidad». ${ }^{13}$

\footnotetext{
8 «Vence el mundo nuestra fe».

9 Goncourt, E. \& Goncourt, J. Op. cit., p. 10-11.

10 Slosmanis, B. Op. cit., p. 10.

11 Beauvorr, S. Le deuxième sexe II. París, Gallimard, 1976, p. 217.

12 Ibid., p. 195.

13 Ibid., p. 208.
} 
Desgraciadamente, esta forma de expresar el amor físico entre dos individuos del mismo género no se extiende al terreno emocional en el caso de Agnes e Isa. No existe una «reciprocidad exacta» ya que Isa adquiere la función de sujeto y Agnes la de objeto. Isa es soberana y Agnes esclava; la relación entre las dos jóvenes se vuelve tortuosa y cruel.
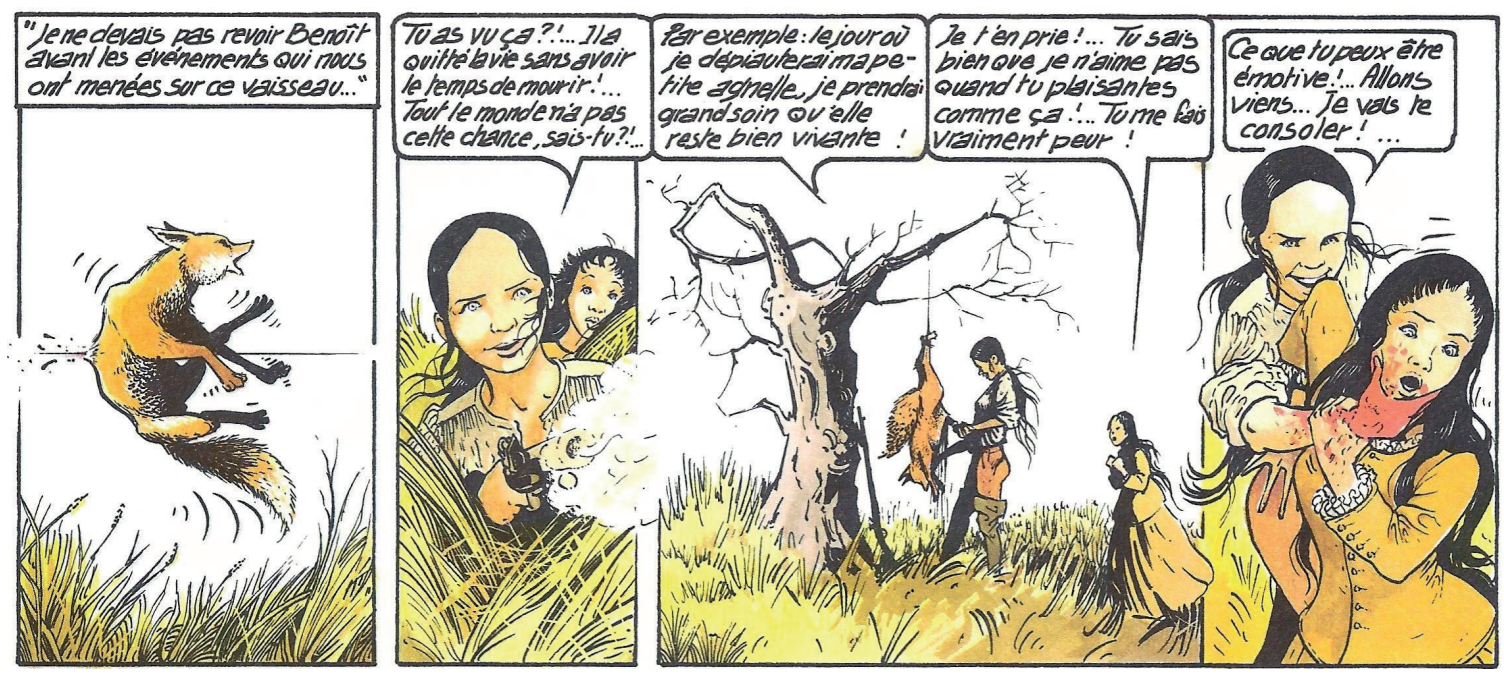

FIG. 3. En la relación homosexual de Isa y Agnes no existe una reciprocidad emocional sino una dominación que Isa ejerce con crueldad ( $« \mathrm{La}$ fille sous la dunette», Glénat, 1979, p. 27).

Un ejemplo de este tipo de relación de dominación la vemos en una breve secuencia en la que Isa mata de un disparo a un zorro y le comenta a Agnes: «[El zorro] ha dejado la vida sin tener el tiempo de morir. Todo el mundo no tiene esa suerte» (FIG. 3). Luego, mientras despelleja al animal, continúa: «Por ejemplo, el día en que despelleje a mi pequeña Agnes tendré mucho cuidado de que esté bien viva» («La fille sous la dunette», p. 27). Agnes percibe la crueldad de Isa y reconoce tener miedo, pero se sabe derrotada y confiesa: «Yo no podría vivir sin ti. Tú lo sabes y abusas de ello» («La fille sous la dunette», p. 28). ${ }^{14}$

\section{La elocuencia}

«La lengua es la espada de las mujeres, porque su debilidad física les impide combatir con el puño; su debilidad mental las hace prescindir de argumentos válidos, por lo que solo les queda el exceso de palabras». ${ }^{15}$ Esta frase del doctor Paul Julius Moebius (1853-1907) reconoce, en cierto modo, la habilidad de las mujeres con la palabra, pero trata de minusva-

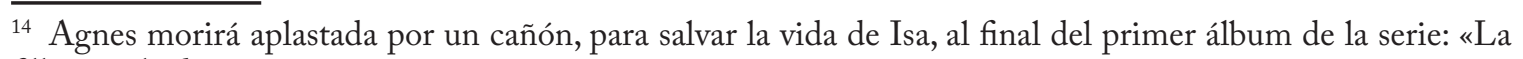
fille sous la dunette».

${ }_{15}$ Moebius, P. J. La inferioridad mental de la mujer. Barcelona, Bruguera, 1982, p. 11. 
lorarlas exponiendo que su discurso, al carecer de fundamento, degenera en una verbosidad sin valor alguno. ${ }^{16}$

Moebius acepta que la mujer posee un cierto intelecto, pero que este talento femenino solo es una apariencia cuyo objetivo es promover la fantasía en el hombre que desea conquistar. Para ejercer su poder de atracción hacia el varón, la joven:

se interesará, aunque solo sea en apariencia, seriamente en todas las cuestiones posibles; formará juicios, combatirá; en suma, aparecerá llena de esprit y genial en asuntos amorosos. Luego dejadla que tenga marido y la veréis distinta. La mujer fogosa y a menudo brillante se transformará en una mujer afable y simple. ${ }^{17}$

Para Moebius esta «mujer afable y simple» es consecuencia de la pérdida de las facultades mentales por lo que «la mujer, como suele decirse, entontece». ${ }^{18}$

Esta idea de que «la mujer está dotada de una capacidad mental inferior a la del hombre y [que], además, la pierde prematuramente» ${ }^{19}$ se incorporó a la conciencia colectiva y se extrapoló para todas las actividades tanto sociales como artísticas. A modo de ejemplo examinemos dos obras de uno de los grandes escritores en lengua inglesa: Retrato de una dama ${ }^{20}$ y Las bostonianas ${ }^{21}$ de Henry James (1843-1916).

La protagonista de Retrato de una dama, Isabel Archer:

era una joven muy propensa a teorizar y poseía una imaginación notablemente activa. Tenía la fortuna de ser más inteligente que la mayoría de las personas que trataba, de percibir con más sutileza todo cuanto la rodeaba y de tener un ansia de saber fuera de lo corriente. ${ }^{22}$

Sin embargo, esta mujer, de grandes cualidades y amante de su independencia, contrae matrimonio con un hombre que realmente la quiere por su dinero, Gerald Osmond. Primero, él ya le había advertido que ella «tenía demasiadas ideas y que debía deshacerse de ellas»;23

\footnotetext{
de género.

17 Moebius, P.J. (1982) Op. cit., p. 23.

18 Ibid., p. 24.

19 Ibid., p. 21.

20 James, H. Retrato de una dama. Barcelona, Thassàlia, 1997.

${ }^{21}$ James, H. Las bostonianas. Barcelona, Mondadori, 2006.

22 James, H. (1997) Op. cit., p. 56.

${ }^{23}$ Ibid., p. 470.
}

${ }^{16}$ Con el paso del tiempo se ha visto que esta afirmación estaba basada en una premisa falsa: la debilidad mental de la mujer con respecto al hombre. Una vez que no se le impidió a la mujer el acceso a los mismos estudios que el hombre disfrutaba, la integración de la mujer en todos los campos del saber y su aportación intelectual no se diferenciaba de la del hombre, simplemente porque el conocimiento es único y no entiende 
luego, se sintió profundamente avergonzado porque Isabel tenía «una mente propia. Su mente debía pertenecerle a él, adosarse a la de él como una pequeña parcela ajardinada a un bosque poblado de ciervos»; ${ }^{24} \mathrm{y}$, finalmente, la amante de Gerald Osmond, Madame Merle, refiriéndose al estado mental de Isabel dice: «tu mujer no sabe qué hacer consigo misma... Esta mañana no pudo mostrarme ni una [idea]. Parecía hallarse en un estado mental muy simple, casi estúpido. Estaba completamente perpleja». ${ }^{25}$

En Las bostonianas, Henry James nos presenta a una mujer excepcional en la comunicación oral, Verena Tarrant. Había adquirido una notable fama como oradora y se había convertido en un referente para el movimiento feminista, pero se enamora de un hombre pobre, Basil Ransom, que le hace «sentir que era más atractiva la idea de entregarse a un hombre que al movimiento [feminista]». ${ }^{26}$ Osmond pensaba que las mujeres eran «seres superficiales» ${ }^{27}$ y que el talento de Verena era «una mera ilusión $»^{28}$ porque solo es «el don de la expresión [oral]», ${ }^{29}$ no el de una auténtica inteligencia.

El triunfo del hombre (Basil Ramson) y la sumisión de la mujer (Verena Tarrant) se manifiestan en el texto siguiente:

Era evidente que Verena había renunciado a todo, a cualquier pretensión de sostener convicciones diferentes [a las de Osmond] y de mantener alguna lealtad a la causa feminista; todo se había derrumbado. ${ }^{30}$

En los ejemplos que acabamos de exponer, parece que Henry James sigue las pautas descritas por Moebius; primero, crea un personaje femenino envuelto en un manto de aparente inteligencia y, luego, la desvela como un ser limitado que se somete a su marido.

En las antípodas de estos personajes de Henry James se encuentran las protagonistas de Los pasajeros del viento, Isa y Mary; ellas, pese a vivir en un mundo regido por normas que favorecen al hombre, logran enfrentarse con éxito a situaciones difíciles para su género conservando su propia personalidad. «La importancia tomada por la mujer en Los pasajeros del viento, como ser autónomo, completo, y no como faire-valoir u objeto sexual de los héroes masculinos» ${ }^{31}$ es manifiesta y es el reflejo de las mujeres que, en cualquier época, han desafiado la autoridad masculina. Este tipo de desafíos desconcierta y modifica el comporta-

\footnotetext{
${ }^{24}$ Ibid., p. 474.

${ }^{25}$ Ibid., p. 569.

${ }^{26}$ James, H. (2006) Op. cit., p. 456.

${ }^{27}$ Ibid., p. 462.

${ }^{28}$ Ibid., p. 458.

${ }^{29}$ Ibid., p. 459.

30 Ibid., p. 522.

31 Pierpoint, J. Op. cit., p. 24
} 
miento del hombre, de modo que «la dependencia radical del sujeto masculino respecto del "otro" femenino revela de pronto que su autonomía es irreal». ${ }^{32}$

A lo largo de la obra hay numerosos ejemplos de la lucidez verbal de las mujeres. Tomemos como ejemplo las repuestas que Isa da a sus compañeros de viaje, en el barco negrero $M a-$ rie-Caroline, en relación con el tema de la esclavitud en el libro «Le comptoir de Juda» (FIG. 4).

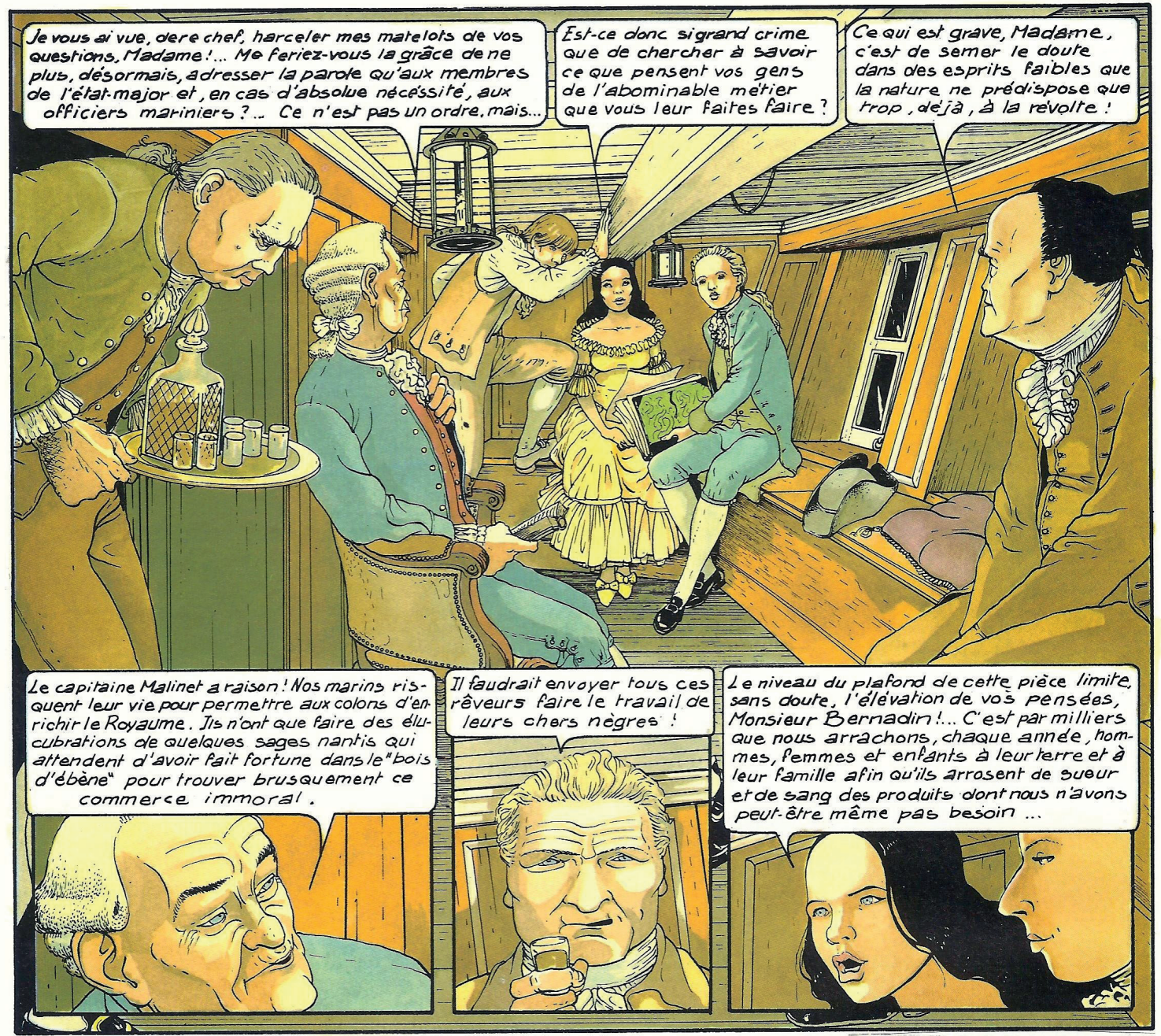

FIG. 4. Isa es advertida de que no debe dirigir la palabra a los marineros del barco negrero $M a-$ rie-Caroline para indagar sobre lo que piensan de la esclavitud. Isa rebate con habilidad los argumentos de quienes tratan de justificar la esclavitud («Le comptoir de Juda», Glénat, 1981, p. 6).

32 Butler, J. El género en disputa. Barcelona, Paidós, 2007, p. 36. 
El primer teniente, Bernardin, amenaza con que «sería necesario enviar a todos estos soñadores [como Isa] a hacer el trabajo de sus queridos negros»; ella le replica:

El nivel del techo de este camarote [aproximadamente de 1,50 m] limita, sin duda, la elevación de sus pensamientos, señor Bernardin. Son por millares los hombres, mujeres y niños que cada año arrancamos de su tierra y de su familia con el fin de regar de sudor y sangre los productos de los que ni siquiera tenemos necesidad. («Le comptoir de Juda», p. 6).

El cirujano Jean Rousselot alaba la nobleza de las ideas de Isa, pero alude que estas no tienen cabida en este mundo pues la esclavitud ha existido siempre: «ंRealmente piensa poder cambiar una de las más duras, quizás, pero también de las más antiguas leyes de la vida [1a esclavitud]?». Ella le increpa: «¿Qué hay más duro, más injusto y sobre todo más ineludible que la muerte, señor cirujano? Sin embargo, ¿no ha elegido usted combatirla cada día de su vida? («Le comptoir de Juda», p. 6).

El marinero y pareja de Isa, Hoel, ${ }^{33}$ quiere persuadirla para que abandone sus ideas abolicionistas ya que nadie se va a interesar por la suerte de los esclavos, porque el pueblo tiene bastante con su miseria y los nobles son indiferentes a que la gente reviente de hambre. Ella se mantiene firme en su altruismo:

Unos son ciegos de nacimiento [el pueblo] y los otros rehúsan abrir los ojos [los nobles] ¿Qué pasará si aquellos que ven con claridad se niegan a tomar el timón cuando se acerque la tormenta? ¡El mundo pertenece a todos aquellos que viven en él, Hoel! Les guste o no, los que se aprovechan deberán, algún día, rendirse a esta evidencia. («Le comptoir de Juda», p. 8)

Finalmente, escuchemos la conversación entre el abad del fuerte Juda e Isa sobre la religión de los negros. El abad la consideraba extraña en cuanto al uso de la sangre como vehículo de comunicación con los dioses («Le comptoir de Juda», p. 30):

Isa: Allí donde no queremos ver más que barbarie, habría un acto religioso comparable a aquel que le lleva a usted, cada día, a beber la sangre de Cristo.

El abad: La analogía es audaz pero no os seguiré por esa pendiente arenosa.

Isa: Es por un terreno más movedizo por el que usted sigue a una Iglesia que, predicando el amor al prójimo, no duda en hacerse cómplice y aliada de los mercaderes de esclavos.

$\mathrm{El}$ abad: Ad maioren Dei gloriam... ${ }^{34}$

${ }^{33}$ Hoel es un joven marinero bretón de origen humilde que será la pareja Isa durante los cinco primeros álbumes de la serie. Realmente, Isa y Hoel tienen poco en común; Hoel, como personaje, solo tiene la función de resaltar el papel de la heroína: Isa. Cuando el destino les lleva por diferentes caminos, Isa sufre un cierto desasosiego por la ausencia de Hoel, pero en su reencuentro, tras veinte años de separación, no tendrán nada que decirse.

34 «Para la mayor gloria de dios», divisa de la Compañía de Jesús, orden religiosa fundada por San Ignacio de Loyola. 
No debería sorprendernos que Isa abrace la causa abolicionista porque la situación legal de la mujer en el siglo XviII no era mejor que la del esclavo en cuanto a la ley como vimos más arriba. Esta opresión de la mujer continuaría durante el siglo siguiente como denuncia el filósofo y economista John Stuart Mill (1806-1873): «No es mi propósito afirmar que las mujeres no sean en general mejor tratadas que los esclavos; pero sí digo que no hay esclavo cuya esclavitud sea tan completa como la de la mujer». ${ }^{35}$ La lucha contra la esclavitud es, en cierto modo, la lucha por la liberación femenina; Isa no podrá llevar a cabo sus ideales sobre la esclavitud, pero su vida será lo suficientemente larga para que presencie el final de la esclavitud en el mundo occidental. Isa vivió como un ser independiente en un entorno poco favorable a la participación de la mujer en la vida pública, pero no asistió a la liberación económica y social de la mujer que tuvo lugar, en el siglo xx, cuando mujeres radicales como ella lograron ser escuchadas.

\section{La seducción}

En el siglo de las luces, los bailes, las recepciones, las visitas, el espectáculo y el amor son las principales distracciones de la nobleza. No hay descanso; siempre la agitación y el ruido. Pero es en el libertinaje donde esta disipación alcanza su paroxismo. El ideal del amor es el deseo, y el amor es la voluptuosidad, un juego en el que reina el cinismo. La mujer es la presa que los hombres codician.

Supremo refinamiento de la corrupción del hombre, la moda es hacerse amar por la mujer, para dejarla enseguida, a fin de confundir su amor propio. Con el objeto de destruirla, el hombre provoca en ella, no solo el deshonor, sino sus sufrimientos. ${ }^{36}$

En una sociedad con esos valores no es de extrañar que afloren casanovas como Estienne de Viaroux, tenedor de libros en el fuerte de Saint-Louis de Juda en la Costa de los Esclavos de África.

La llegada de Isa y Mary ${ }^{37}$ al fuerte de Juda causa gran expectación en la pequeña comunidad francesa compuesta exclusivamente por hombres. Viaroux apuesta, con el director del fuerte Olivier de Montaguere y el señor Genest, que obtendrá el favor de las dos damas «doblándolas a su voluntad» si se le condonan sus deudas de juego («Le comptoir de Juda», p. 13).

La galantería que Viaroux tributa a las damas es excesivamente directa, impertinente y de dudoso gusto, incluso para aquella época. Veamos dos ejemplos significativos. En el primero, Viaroux le enseña a Mary frutas exóticas que ella desconocía y se insinúa con una metáfora: «Estoy seguro que su jardín contiene frutos maravillosos». Mary le deja claro

35 Mill J. S. La esclavitud femenina. Edición iBook, J. Borja, 2014.

36 Slosmanis, B. Op. cit., p. 12.

${ }_{37}$ Mary Hereford es una joven inglesa hija de un rico comerciante. Al quedarse embarazada del teniente Smolett, su padre la aísla en la campiña para que se desprenda del bebé. Ella decide conservarlo y huye de Inglaterra en compañía de su profesora de francés: Isa (FIG. 1). Mary estará presente en la obra Los pasajeros del viento desde el álbum $2 .^{\circ}$, «Le Ponton», hasta el 5.०, «L'heure du serpent». 
que ella manda en su cuerpo: «Soy yo la que elige al jardinero» («Le comptoir de Juda», p. 16). En el segundo, Viaroux previene a Mary del peligro de pasear por la sabana africana sin escolta y vuelve a insinuarse mediante un fingido lamento: «Me es insoportable imaginarme vuestro cuerpecito entre las garras de una fiera». La referencia al cuerpo femenino como signo de placer y de debilidad conlleva un doble mensaje: el primero es de seducción y pone a prueba la virilidad de Viaroux; y el segundo es de protección de Mary contra sí misma dado el comportamiento irreflexivo habitual de las mujeres. Esta construcción tan masculina se desmorona con una simple frase de Mary: «A mí, lo que me es insoportable de imaginar, es mi pobre cuerpecito lidiando con vuestra imaginación» («Le comptoir de Juda», p. 26).

Una forma de obtener el derecho de disfrute de una o varias hembras en el reino animal es a través de la lucha con otros machos. De modo semejante, el hombre utiliza la figura del duelo para resolver disputas de toda índole o para la restauración del honor. El comportamiento de Viaroux con Isa hace que entre Hoel y Viaroux se plantee la posibilidad de ejercitarse con la espada. Isa muestra a Hoel su mayor capacidad, como mujer, para resolver situaciones de este tipo: «Sé prudente [Hoel], yo estoy mejor armada que tú para espantar a este tipo de vanidoso» («Le comptoir de Juda», p. 14).

Sin embargo, Mary no pudo evitar el duelo entre su pareja, Smolett, y Viaroux. Cuando se inicia el duelo, Mary pone de manifiesto lo ridículo de la situación con una visión muy femenina: «Es una idea fija, vuestras espadas. ¿No podéis lavar vuestro honor de otra forma? El boxeo o hacer un pulso... Es igual de idiota pero menos dañino» («L'heure du serpent», p. 40).

Pero, una vez iniciada la lucha, en una zona pantanosa, los contrincantes no pueden parar; ya no piensan en la causa de la lucha, Mary, sino en sí mismos. Esta es la idea que Thomas Mann (1875-1955) expone en su obra Las cabezas trocadas, utilizando como vehículo al personaje femenino de Sita. Ella, ante los cuerpos sin vida de su esposo y de su amigo, reflexiona:

Han actuado como hombres feroces y ni por un momento han pensado en mí. Es decir, pensaron en mí; yo, pobre de mí, era el objeto de su terrible virilidad, y esto me hace estremecer hasta cierto punto; pero solo pensaron en mí con relación a sí mismos, no con relación a mí y a lo que a mí habría de suceder. ${ }^{38}$

Al ver desaparecer a Smolett y Viaroux bajo las aguas del pantano en la oscuridad de la noche, Mary siente la misma aflicción que Sita (FIG. 5). Sin embargo, hay una notable diferencia: Sita ha sido educada en la cultura hindú y la expresión de sus sentimientos así lo reflejan, porque es una mujer dependiente que se siente culpable y ve con preocupación su futuro: «¿Debo vagar, viuda, por la vida y llevar la mancha y el oprobio de la mujer que ha cuidado tan mal a su dueño como para que él pereciera?». ${ }^{39}$ Mary se siente triste pero no

\footnotetext{
${ }_{38}$ Mann, T. Las cabezas trocadas. Barcelona, Edhasa, 2002, p. 72.

39 Idem.
} 


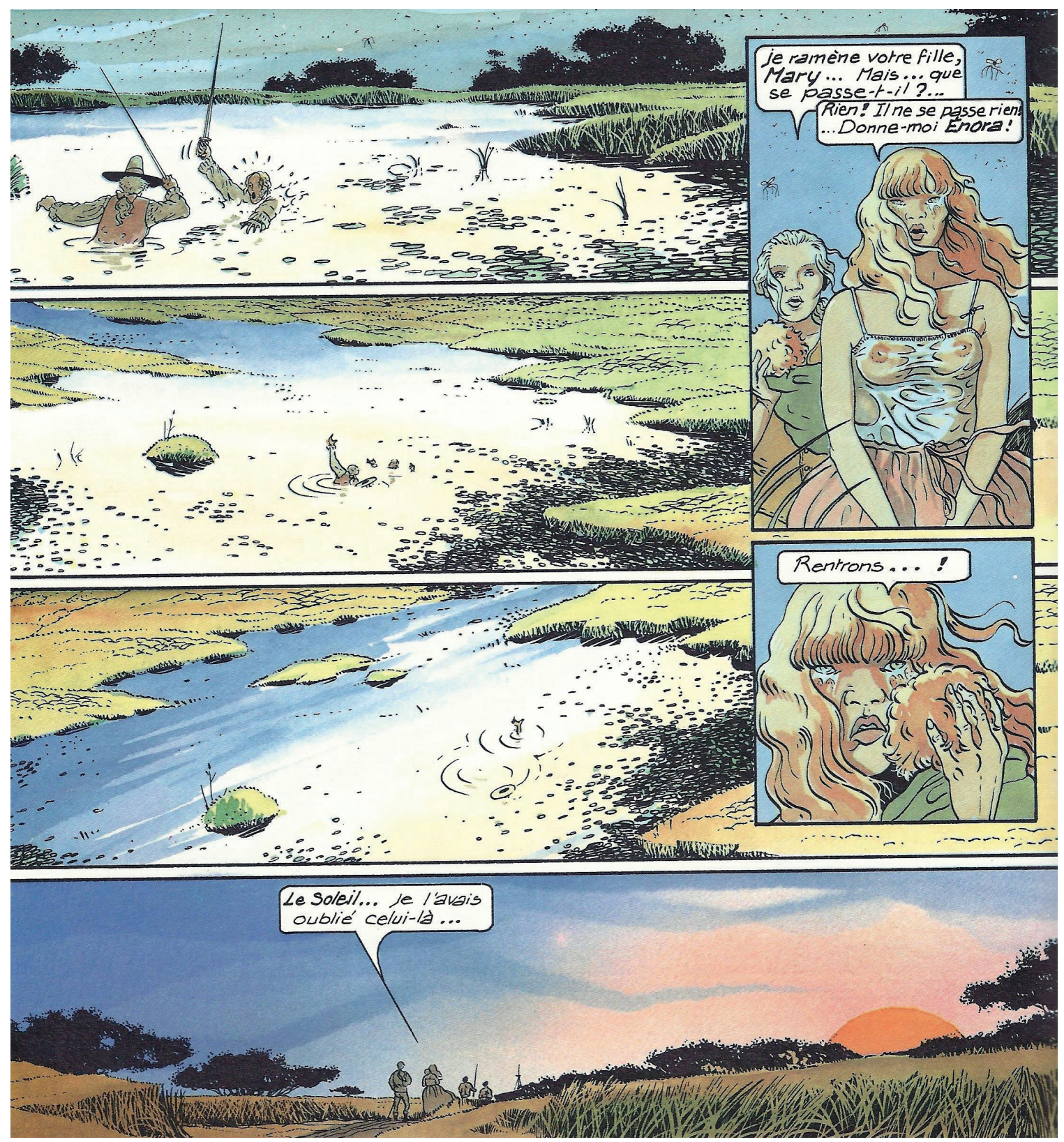

FIG. 5. Smolett y Viaroux, en el fragor de la lucha, desaparecen bajo las aguas del pantano. Mary se siente triste, pero no culpable. Ella fue el objeto del duelo pero ellos perecieron victimas de su propio egocentrismo ( $L$ L'heure du serpent», Glénat, 1982, p. 42).

culpable; ella fue el objeto de duelo, pero no la causa de la muerte de Smolett y Viaroux, que fueron presa de su egocentrismo y su estupidez; ella no teme al futuro y lo expresa con una sencilla frase, en la viñeta final de esta trágica secuencia en la que la noche da paso al día: «El sol... Yo lo había olvidado» («L'heure de serpent», p. 42). 
La figura del casanova ha sido posible por la pasividad de la mujer a la hora de elegir su pareja. Ella no debe mostrar sus sentimientos; al contrario, debe ocultarlos, debe dejarse seducir, desplegar su encanto físico y enviar señales que alienten al varón a encontrar el valor para declarar su amor. Por ello:

En los asuntos amorosos, la mujer se considera [...] como un objeto; deja que se le aproximen, no elige libremente, no se convierte en el sujeto del amor hasta que no ha elegido el hombre, e incluso en ese momento su libertad de elección está muy restringida y disminuida por el mero hecho de haber sido ella el objeto elegido. ${ }^{40}$

Pero no todas las mujeres mantienen esta pasividad frente al amor. Siempre han existido mujeres que han tomado la iniciativa y elegido libremente al hombre que deseaban, prescindiendo de toda conveniencia social, moral y sin temor a ser consideradas «mujeres fáciles» por haber actuado del mismo modo que lo hacen los varones.
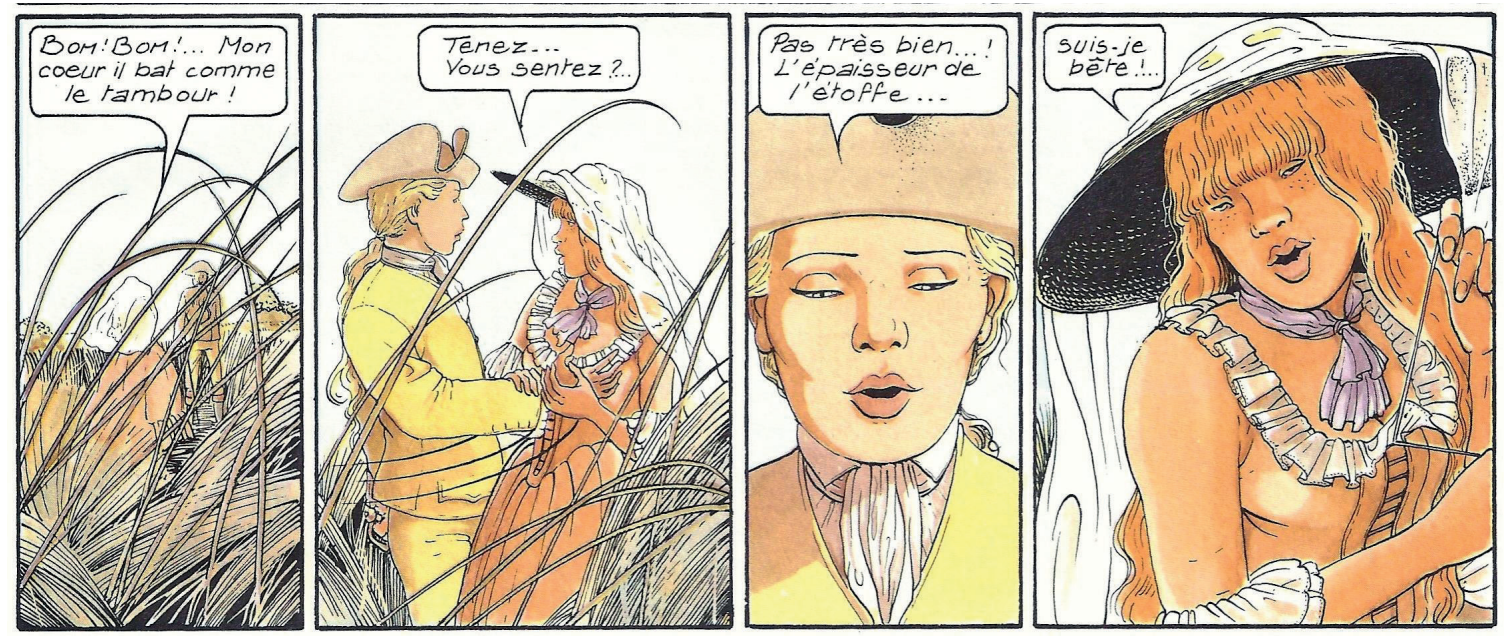

FIG. 6. Mary seduce al joven teniente François

Vignebelle. Ella le pide que palpe con su mano el fuerte latido de su corazón. Como el tejido del vestido es grueso, Mary se dispone a solventar esta dificultad («Le comptoir de Juda», Glénat, 1981, p. 25).

En asuntos amorosos, Isa y Mary pertenecen a este tipo de mujer que elige libremente a su pareja; ellas no se comportan como el objeto que deja que el hombre tome la iniciativa sino que actúan como sujeto. Sin embargo, esta forma de proceder en el amor no es siempre entendida por el hombre común; así cuando Isa propone, abiertamente, a Hoel tener una relación sexual, este la compara con el diablo. Ella le demuestra lo absurdo de su acusación al afearle su comportamiento: "iVaya! Un buen hombre empolvado manda a un pobre tipo a asesinarte; tú te descubres ante él y le llamas "Señor comandante", pero si una joven te

${ }^{40}$ Mann, T. La montaña mágica. Barcelona, Edhasa, 2005, p. 783. 
propone intercambiar un poco de ternura: ella es un discípulo de Satanás» («La fille sous la dunette», p. 17).

Mary no tiene ningún reparo en seducir al joven teniente François Vignebelle (FIG. 6), pero su osadía puede atemorizar a un hombre sin experiencia, al punto de no poder estar a la altura de las circunstancias en el lance. Mary sabe conjugar la pasión con la ternura y encuentra las palabras justas para consolar a François: « $¡$ No es grave, François! La primera vez es con frecuencia así... pero no tiene importancia. Los hombres creéis que siempre debéis demostrar alguna cosa... pero nadie os pide nada» («L'heure du serpent», p. 33).

\section{El vestido}

El vestido tiene su origen en la protección del cuerpo frente a una climatología adversa. Absuelto de esta función, el vestido adquiere la condición ornamental para realzar la apariencia física o para poner de manifiesto la posición social entre los individuos de una comunidad (FIG. 1). «Por su visibilidad, [el vestido] es concebido como un mensaje, colectivo o individual, consciente o inconsciente, que aquel que lo lleva se dirige a sí mismo y a los demás». ${ }^{41}$

Hoy, en el mundo occidental, las mujeres han logrado tener, en teoría, los mismos derechos que los hombres en la mayor parte de las actividades que se desarrollan en el ámbito social y laboral. Sin embargo, la idea de considerar a la mujer como un objeto ${ }^{42}$ sigue estando aún arraigada en la sociedad; el cuerpo femenino se somete a una continua evaluación y obliga a la mujer a mostrarse bella en todo momento; la apariencia ante los demás se convierte en una obsesión y la ropa que la envuelve en la prolongación de la identidad femenina: la belleza.

La última tiranía que se ejerce sobre la mujer es a través de su vestuario y su dictado es la moda. La utilización de ropa incómoda que impide el libre movimiento del cuerpo o de un calzado inadecuado para caminar, que obliga a que el pie adopte posturas imposibles, es la norma que parece regir el canon de belleza femenina.

En el siglo XviII, la moda sigue la transformación de la fisionomía de la mujer y la gran variedad de la ropa femenina puede verse a través del arte, «ese espejo mágico donde la coquetería del pasado sonríe aún». ${ }^{43}$ En Los pasajeros del viento, «el vestido justificaría por sí mismo un estudio específico en tanto que las fuentes son precisas, diversas y significativas». ${ }^{44}$

${ }^{41}$ Cassagnes-Brouquet, S. \& Dousset-Seide, C. «Genre, normes et langages du costume», en Clio. Femmes, Genre, Histoire [En ligne], n. ${ }^{\circ} 36$ (2012), p. 7.

42 Un hombre galante trata a Isa como a un objeto al decirle: «[a los] veintiocho años no me esperaba verla tan fresca». Ella le contesta irónicamente: "Qué delicadeza. Usted me halaga. La "cosa" le agradece el cumplido que hace al valor de su carne» («La petite fille Bois-Cäiman», libro 2. ${ }^{\circ}$, p. 22).

${ }^{43}$ Goncourt, E. \& Goncourt, J. Op. cit., p. 313-380.

44 Thiе́вaut, M. Le chemin de l'Atchafalaya. Tournai, 12bis, 2010, p. 95. 
La ropa femenina, al final del Antiguo Régimen, no era fácil de llevar debido a su gran amplitud y a los diversos accesorios que incluía. La complejidad de un traje de «ceremonia a la francesa» se muestra cuando Mary se está vistiendo para una «pequeña fiesta» en el fuerte de Juda (FIG. 9): «Mary ha atado a su cintura un gran "tontillo" de forma elíptica. ${ }^{45}$ Su busto está aprisionado por un gran corsé abierto sobre el pecho y recubierto de damasco de seda». ${ }^{46}$ Isa prefiere ropa más sencilla y para esa ocasión lleva un vestido «a la polonesa», que se lleva sin tontillo y que su parte trasera se eleva por tres cordones («Le comptoir de Juda», p. 16).

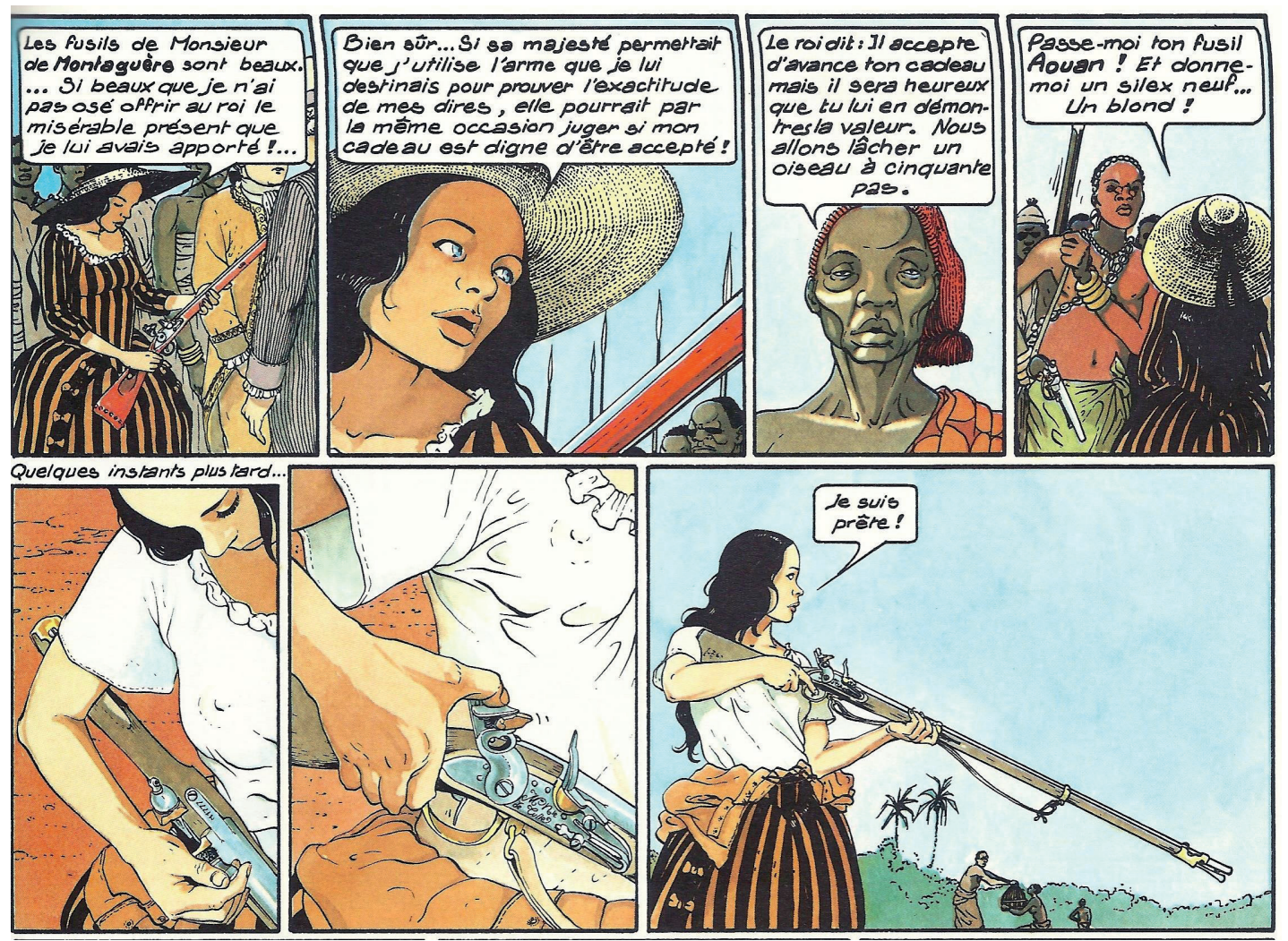

FIG. 7. En la corte de Kplënga, Isa lleva un discreto vestido a la inglesa de grandes líneas verticales, ajustado a la cintura y con un pequeño armazón para realzar las caderas. Pese a la ligereza del vestido, resulta incómodo para el uso de un fusil, por lo que Isa debe soltarse el peto ( $L$ L'heure du serpent», Glénat, 1982, p. 11).

En la corte africana de Kpëngla, Isa portará un vestido a la inglesa de dos piezas, falda y mantillo; el tejido de la falda lleva impresas «grandes líneas verticales [que] reflejan el gusto de la época por la línea recta» ${ }^{47}$ (FIG. 7).

\footnotetext{
${ }^{45} \mathrm{E} 1$ tontillo es un armazón interior que se utilizaba para ahuecar la falda de un vestido.

46 Thí́вaut, M. Les chantiers d'une aventure. Tournai, Casterman, 1994, p. 51.

${ }^{47}$ Ibid., p. 53.
} 
Durante el Directorio, el vestido femenino, desprovisto de tontillo y otros artilugios, libera el cuerpo de la mujer dándole a su silueta un aspecto natural; en esta época vemos a Isa con un vestido de color blanco; la falda cae recta al suelo y se sujeta justo debajo del pecho con una banda de color (FIG. 8).

La ropa del hombre es más cómoda de llevar que la de la mujer y ofrece mayor libertad de movimiento; pero es por el miedo a esa libertad que los hombres, hasta no hace mucho tiempo, impedían que las mujeres pudieran utilizar ropa semejante a la de ellos. En Los pasajeros de viento esta forma de pensar se hace patente: un hombre detesta que una mujer [Isa] vista de hombre («Le bois d'ébène», p. 19); otro ve la ropa masculina como impúdica

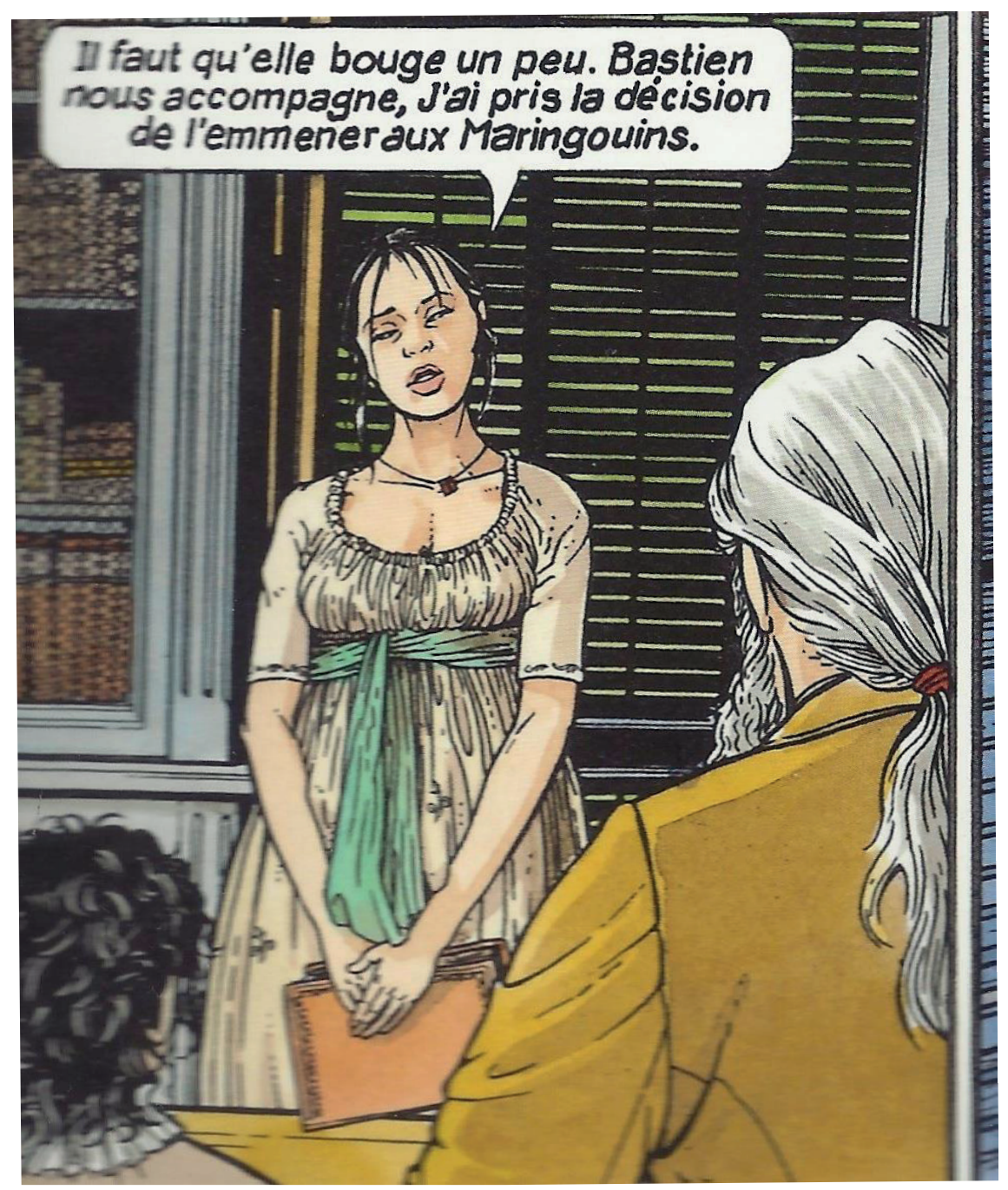

FIG. 8. Durante el Directorio el vestido de la mujer se hace más ligero y permite mayor libertad de movimiento. Isa lleva un vestido blanco que se sujeta bajo el pecho con un cinta de color. («La Petite Fille Bois-Caïman», libro 2. ${ }^{\circ}, 12 \mathrm{bis}$, 2010, p. 43). 
cuando es una mujer [Isa] quien la lleva («L'heure du serpent», p.22); aquel otro alaba la belleza de Isa cuando se viste de mujer al tiempo que lamenta que se pasee por la cubierta del barco vestida de hombre («la fille sous la dunette», p. 18); y un último, un cura, reflexiona sobre ello entre la censura y la tolerancia:

Hace algunos años, habría lanzado un anatema sobre la mujer que, para caminar por la maleza, tuviera la desfachatez de vestirse de hombre. $\mathrm{Al}$ atardecer de la vida se dejan los prejuicios con las ilusiones. El ojo envejecido ignora el detalle y solo distingue la sombra o la luz... Se creería que en usted [Isa] hay algo luminoso («Le comptoir de Juda», p. 32).

Isa logra un equilibrio en el uso de la ropa femenina y masculina. La primera la utiliza, principalmente, para relacionarse socialmente y para proyectar una imagen que agrade tanto a sí misma como a los demás, pero evitando la incomodidad. La segunda, para interaccionar con la naturaleza, vivir en libertad y para poder reaccionar con rapidez frente a situaciones de peligro.

\title{
Maternidad
}

Para Paul Julius Moebius, «la naturaleza exige de la mujer amor y abnegación maternales [...] La hembra debe ser, ante todo, madre». ${ }^{48}$ Esta forma de pensar llevaba implícita la idea de que el destino de toda mujer y la única razón de su existencia es la maternidad, ya que al varón es a quien corresponde desempeñar el papel activo en la sociedad. La población masculina, en general, compartía esta idea de la separación de roles sociales según el género, pero no la manifestaba con franqueza; Stuart Mill es quien levanta el velo de la hipocresía:

\begin{abstract}
Me gustaría que alguien lo confesase con franqueza y viniese a decirnos: «Es necesario que las mujeres se casen y tengan hijos, pero no lo harán sino por la fuerza. Luego, es preciso forzarlas». Este lenguaje franco se parecería al de los defensores de la esclavitud en la Luisiana: «Es preciso, decían, cultivar el algodón y el azúcar. El hombre blanco no puede, el negro no quiere por el precio que le queremos pagar. Ergo, es preciso obligarle». ${ }^{49}$
\end{abstract}

Una de las conclusiones más atrevidas que ofrece Simone de Beauvoir, en El segundo sexo, es la no existencia del instinto maternal: «La palabra no se aplica en ningún caso a la especie humana. La actitud de la madre está definida por el conjunto de su situación y por la forma en la que lo asume». ${ }^{50}$ En una entrevista concedida en 1976 a la revista Der Spiegel, ella añade que «la maternidad es hoy una auténtica esclavitud [...] Si a pesar de todo una mujer quiere tener un hijo, debería hacerlo sin casarse. La pareja es la mayor trampa». ${ }^{51}$

\footnotetext{
${ }_{48}$ Moebius, P. J. Op. cit., p. 16.

${ }^{49}$ Mill, J. S. Op. cit.

50 Beauvoir, S. (1976) Op. cit., p. 369.

51 Schwarzer, A. «"Das Ewig Weibliche ist eine Lüge”, Simone de Beauvoir im Gespräch mit Alice Schwarzer», en Der Spiegel, n. ${ }^{\circ} 15$ (1976). Edición en e-book.
} 
Isa y Mary van a ser madres, pero su maternidad se desarrolla bajo condiciones especiales, como veremos a continuación.

\section{La maternidad de Mary}

Mary, al quedarse embarazada del teniente John Smolett, es aislada por su padre en una mansión familiar en el campo en compañía del personal de servicio y de una extranjera: Isa. El objetivo de este aislamiento es ocultar el escándalo de tener descendencia sin estar casada. No sabemos el destino que le estaba reservado al niño (en este caso una niña llamada Enora), pero Mary no deseaba desprenderse de él por lo que planea huir de Inglaterra con Smolett e Isa (FIG. 1).

¿Cómo la juzgaría la sociedad? Mary nos lo aclara: «una miserable pecadora [que debería hacer] penitencia sin ver a nadie en tanto no se haga luz en [su] cabeza» («Le pontón», p. 26). Mary dará a luz durante la travesía en barco a Noirmoutier (Francia) («Le pontón», p. 39) y luego continuará su viaje hasta África.

Durante la estancia en África, la relación afectiva entre Mary y Smolett se va deteriorando. Él la acusa de haberle convertido en un desertor de la marina británica. El malestar de la pareja se muestra en pequeños detalles, como la conversación que mantiene a causa del vestido con tontillo que Mary ha elegido para la fiesta de bienvenida al fuerte de Sant-Louis de Juda («Le comptoir de Juda, p. 15) (FIG. 9):

Smolett: Con ese ingenio [el tontillo] no vas a poder pasar por la puerta de nuestra habitación.

Mary: Se pliega, ¡triste señor! Se diría que solo has desvestido a señoritas fáciles.

Smolett: «Señoritas fáciles». iQué encantador pleonasmo!

Mary: ¡Te estás volviendo tonto! $Y$ la estupidez es peor que la maldad.

Pese a no estar casados, Smolett cree tener derechos sobre Mary, pero Isa le hace ver, desde un punto de vista feminista, que está en un error:

¡Mary os teme! Usted parece que piensa que haberle hecho una hija [Enora] le da el derecho de vida y muerte sobre ella y de todo lo que la rodea. ¡Ella es el viento! Nunca podrá detenerla entre cuatro paredes. ¡Tómela tal y como es u olvídela! («Le comptoir de Juda», p. 40).

Mary sufre el acoso de Smolett y vive con el temor de una agresión. Debe vivir la maternidad en soledad porque es consecuencia directa de sus decisiones y ahora le toca asumir su parte de culpa:

É1 [John] se ha creído en la obligación de seguirme a causa de Enora. Y yo, porque quería tener a la niña, he creído que deseaba quedarme con el padre. Nos hemos equivocado el uno sobre el otro, pero es él el que está pagando más caro este error. Es terrible verle errar así... tan enfermo... tan solo... y que rechace toda ayuda. («Le comptoir de Juda», p. 42). 

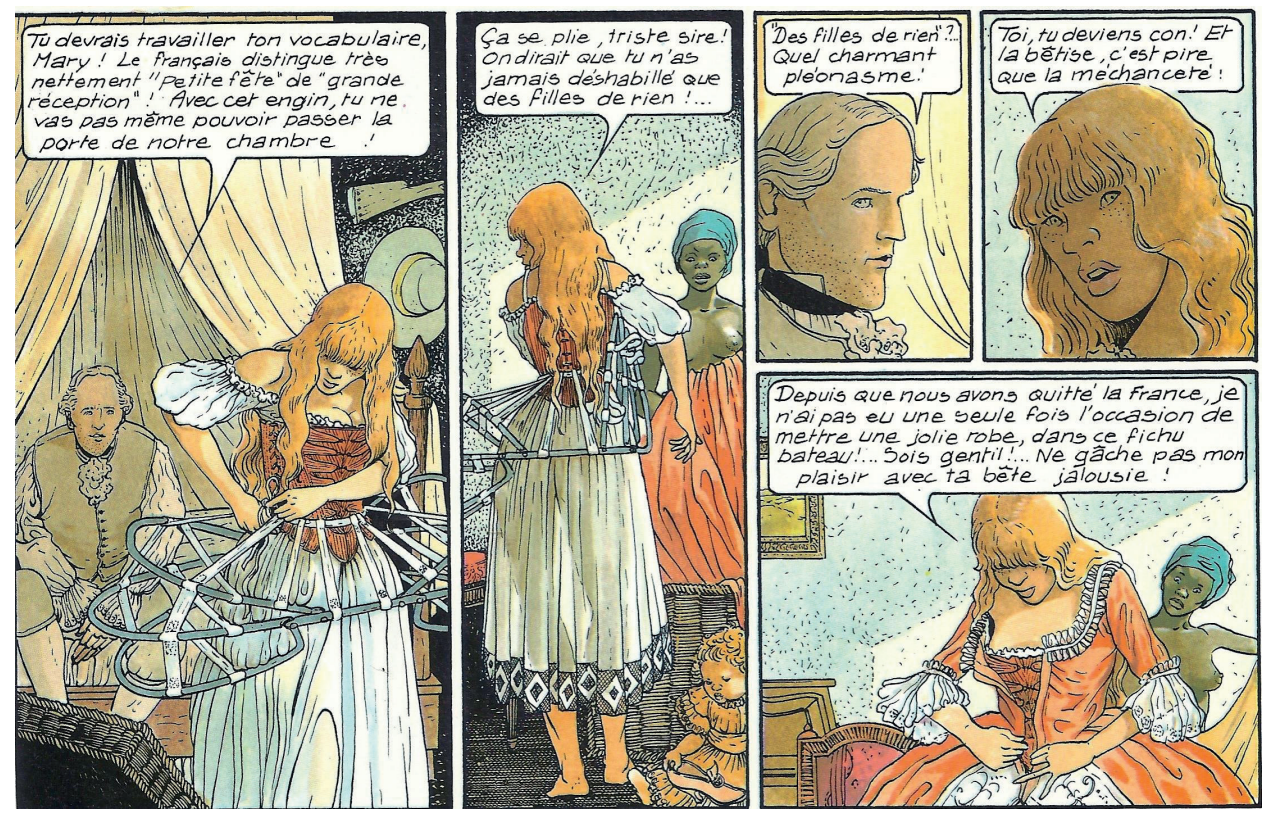

FIG. 9. Mary se viste con un complejo traje de ceremonia francesa para una pequeña fiesta de bienvenida en el fuerte de Juda. El tontillo articulado permite disminuir el amplio volumen del vestido. Este traje no es fácil de llevar, está diseñado para ser mirado, o más bien admirado, no para facilitar la libertad de movimiento. El corpiño ajustado y el zapato de alto tacón, que la niña, Enora, sostiene en su mano, complementan la tiranía que la moda puede ejercer sobre la mujer («Le comptoir de Juda», Glénat, 1981, p. 15).

Hay mujeres que son incapaces de vivir sin la compañía de su pareja, aunque sufran malos tratos, y prefieren la sumisión antes que la soledad; ellas pueden amar más allá de sí mismas. Cuando la situación se vuelve insostenible, siempre es posible un acto de rebeldía, pero en épocas pasadas, la mujer, en muchos casos, no tenía esta opción debido a su dependencia económica, a la ausencia de derechos legales y a las normas sociales que le impedían poder dirigir su vida según sus criterios.

Mary representa aquí a ese tipo de mujer que desea ser madre, pero no se ve en la obligación de tener que compartir su vida con una persona que no quiere. Ella puede vivir sola, o tener otra pareja, ya que se ve capaz de enfrentarse a las costumbres y normas de una sociedad que impedía ser libres a las mujeres.

\section{La maternidad de Isa}

La maternidad de Isa no es voluntaria. Ella la rechaza por atribuirla a una violación colectiva de hombres de raza negra. En este caso particular, las palabras de Simone de Beauvoir sobre el embarazo cobran un peso especialmente terrible: 
El embarazo es sobre todo un drama que se interpreta en el caso de la mujer entre sí misma; lo siente a la vez como un enriquecimiento y como una mutilación; el feto es una parte de su cuerpo, y es un parásito que la explota; ella lo posee y es poseída por él [...] Ella tiene la impresión de no ser nada. Una existencia nueva va a manifestarse y justificar su propia existencia [...] Lo que hay de singular en la mujer embarazada es que incluso en el momento en que su cuerpo trasciende, él es recibido como inmanente. ${ }^{52}$

Isa conoce las repercusiones negativas que conlleva exhibir un retoño mestizo por lo que intentará abortar golpeándose la barriga con un objeto contundente. Este procedimiento bárbaro no surtirá efecto a la hora de librarse de su prole. El alumbramiento de un hijo mestizo por una mujer blanca ni siquiera estaba previsto en el «Código negro», cuyo artículo 9. solo consideraba y sancionaba la relación entre el amo blanco y la esclava negra; no obstante, la aplicación de este artículo no se llevaba a cabo ya que existía una gran tolerancia. ${ }^{53}$ Isa pone en evidencia cómo, ante un mismo hecho, la sociedad favorece al hombre frente a la mujer: "Cuando un hombre deja embarazadas a sus esclavas se alabará su buena vitalidad. Pero cuando una mujer da a luz a un mestizo se dice que es una "puta de negros"» («La petite fille Bois-Cäiman», libro 2. ${ }^{\circ}$, p. 16).

A los ocho meses después de sufrir la violación Isa da a luz, en secreto, a una niña, lo que abre la puerta a que el padre sea su antiguo amante negro, Congo, y no los violadores. Sin embargo, esto es solo una posibilidad, no una certeza («La petite fille Bois-Cäiman», libro $1 .^{\circ}$, p. 84). La presencia de la niña y su gran parecido físico con Isa se justificará, presentándola como la hija que un hermano de Isa habría tenido con una mujer de color; ambos progenitores habrían fallecido en la revuelta de Santo Domingo de 1791. Sin embargo, al no poder probar que la supuesta madre de la niña no era una esclava, esta le es legada a Isa, no como su sobrina, sino como un bien mobiliario transmitido por herencia.

La presencia de la niña es un impedimento para que Isa pueda encontrar una pareja. Sin embargo, un médico viudo, Jean Murray, ${ }^{54}$ se va a sentir atraído por ella. Isa antepone la relación «materno-filial» ante un nuevo horizonte de felicidad conyugal, con un hombre lleno de cualidades, como se muestra en el diálogo siguiente:

Isa: La niña crea obligaciones que asumo voluntariamente, pero me es imposible imponérselas a otra persona.

Jean: Pero la otra persona puede querer compartirlas.

Isa: ¡No me tientes, Jean!

Jean: He recuperado el gusto de vivir, ¿̇me prohíbes hablar de ello?

\footnotetext{
52 Beauvoir, S. (1976) Op. cit., p. 349.

53 Тнí́вaut, M. (2010) Op. cit., p. 86.

${ }^{54}$ Jean Murray, hijo del naturalista Louis Murray, se casará con Isa y vivirán felices, en Luisiana, hasta que él muere en la batalla de Chalmette en 1815. Isa y Jean tuvieron descendencia y su biznieta, Zabo, compartirá protagonismo, en los dos últimos libros de Los pasajeros del viento, con una Isa ya anciana. En este artículo no hablamos de Zabo porque es una mujer del siglo xix.
} 
Isa: Ten cuidado... Si te abro mis noches te quedarás horrorizado de todas mis pesadillas. («La petite fille Bois-Cäiman», libro 2. ${ }^{\circ}$, p. 34)

\section{Literatura y pintura}

En el ensayo Un cuarto propio, Virginia Woolf cita a Dorothy Osborne (1627-1695) que es recordada por una serie de cartas que escribió a quien sería su futuro marido, sir William Temple. Dorothy Osborne no escribió nada porque consideraba que «ninguna mujer discreta y modesta podía escribir libros, [para ella] sus cartas no contaban». ${ }^{55}$

En una sociedad dominada por hombres, el camino hacia la literatura se cerraba para las mujeres, aunque tuvieran grandes cualidades. Sin embargo, una mujer podía escribir cartas porque estas no traspasaban el ámbito de lo personal y carecían de valor artístico. «Una mujer podía escribir cartas sentada a la cabecera de su padre enfermo. Podía escribirlas junto al fuego, mientras los hombres charlaban, sin molestarlos. Lo raro, pensé hojeando las cartas de Dorothy, es el talento que tenía esta muchacha solitaria e inculta para construir una frase, para describir una escena... Hubiera jurado que había en ella la pasta de un escritor». ${ }^{56}$

Isa escribía. Si Virginia Woolf hubiera vivido en la ficción de Los pasajeros del viento y hubiera leído los escritos de Isa, también pensaría de ella, como de Dorothy Osborne, que tenía "pasta de escritor». Veamos un ejemplo en el libro «Le ponton». Se trata de una carta que Isa envía a Hoel cuando él estaba encerrado en un pontón (barco-cárcel) para prisioneros de guerra en medio de un cenagal: «Mary Hereford es una compañía agradable, asombrosamente atrevida para una pequeña burguesa. Esta tarde nos hemos acercado a Medway. Entre dos capas de bruma percibimos tu pontón y tuve miedo. Cada vez que la bruma lo envolvía, me sorprendía al dudar de la realidad de nuestra aventura y, ¿debo decirlo?, de la propia existencia». («Le ponton», p. 8).

${ }_{55}$ Virginia Woolf ejemplifica esta desafección literaria a través de un poema de Anne Finch, condesa de Winchelsea (1661-1720). Woolf, V. Un cuarto propio. Edición en iBook, Penguin Random House Grupo Editorial España, 2013.

¡Ay de mí! A una mujer que ensaya la pluma

la consideran tan presuntuosa

que no hay virtud que pueda rescatar esa falta.

Nos dicen que equivocamos nuestro sexo y camino;

buenos modales, elegancia, baile trajes, juegos,

son los primeros que debemos desear.

Escribir, leer, pensar o investigar,

Nublaría nuestra belleza, agotaría nuestro tiempo,

Estorbaría las conquistas de nuestra plenitud.

La fastidiosa dirección de una casa servil

es para muchos nuestro destino y arte supremo.

56 Ibid. 
Jean Rousselot, cirujano en el barco Marie-Caroline, propone a Isa que escriba un documento sobre la esclavitud en el «Comercio Triangular», para la Sociedad de Amigos de los Negros, fundada por el político Jacques Pierre Brissot (1754-1793).

Isa irá tomando nota de qué acontece en el viaje y cómo es el trato que se dispensa a los esclavos. Los cuatro primeros libros de Los pasajeros del viento están narrados en un estilo directo a través de los diálogos de los personajes, pero en el quinto, «Le Bois d'ébêne», Isa toma la palabra y el relato se estructura a partir de sus escritos, convirtiéndose así en una narración en primera persona. Así vemos pasajes descriptivos (p. 8); narrativos (pp. 30-31; 34-35) o puramente técnicos (p. 32), pero también hay espacio para expresar su estado de ánimo: «Miércoles, 3 octubre 1781. Desde hace tres días viajamos en el corazón de una nube de gaviotas. Los graznidos de las gaviotas son semejantes a las risas y, no sé por qué, estas risas me hielan» (p. 12). Pero sin duda es el texto que cierra este libro el que contiene la mayor carga poética. Describamos la situación para luego leer su texto: Isa había sido encarcelada por impedir que Hoel fuera detenido, en Santo Domingo, por haber matado al comandante Benoît. Cuando sale de la cárcel se encuentra tan desesperada que va a intentar suicidarse en el mar.

Viernes, 29 marzo 1782. Gracias a las relaciones de Madame de Magnan han retirado la demanda contra mí... Soy libre. Libre de soledad... Un poco como en prisión... En estos momentos Mary debe haber alcanzado Nantes. La última carta de Hoel es una carta de adiós. Sola... realmente sola... sin nadie a quién amar ni a quién odiar, ¿o bien odiar al mar?... que tan bien sabe dar, para luego siempre cogerlo todo («Le Bois d’ébêne», p. 47).

Un hecho fortuito hace que Isa desista de su intento de suicidio y continúa en su diario: «Este día, he estado cerca de olvidar que, a fin de cuentas, solo tengo dieciocho años... Y aún toda la vida por delante» (p. 48).

Ya en edad adulta, Isa compone bellos textos como el de la descripción de su modo de vida cuando se retira, periódicamente, a una pequeña cabaña que se construyó al lado del Bayou ${ }^{57}$ Maringouin (FIG. 10):

Estoy encantada de estos tres pedazos de madera que son un nido para el peligro de las crecidas [del río Misisipi]. Este abrigo de fortuna es más que un refugio... En el corazón de ninguna parte, lejos del furor de los hombres y de sus prejuicios, los meandros del gran delta ofrecen una intensa soledad. El cadien reservado, el cazador brusco y el invisible indio son como sombras errantes que van deslizándose sobre el agua y caminando en silencio. Tan pronto como los ves, se evaporan con la bruma. Un café compartido, una sonrisa esbozada, un gesto con la mano son encuentros que marcan las memorias para la eternidad. Yo observo y dibujo. Pesco, cazo y capturo, tanto para la observación como para mi supervivencia. Pero sobre todo exploro y trazo una extensión de libertad para mi hija... («La Petite Fille de Bois-Caïman», libro 2, p.28)

57 Término geográfico que designa a una masa de agua formada por antiguos brazos y meandros del río Misisipi. 


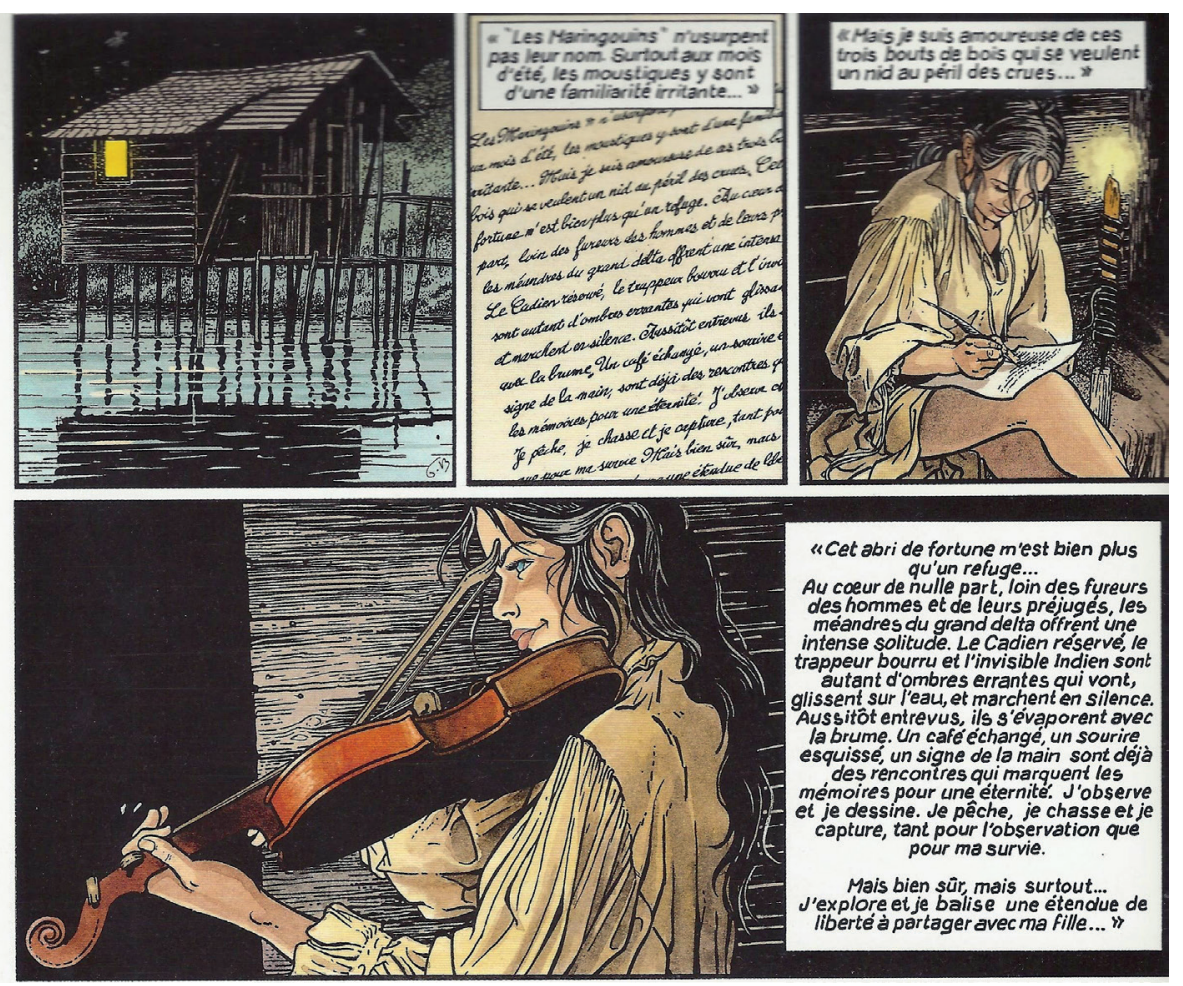

FIG. 10. Una pequeña cabaña en el Bayou de $\mathrm{Ma}-$ ringouin, sirve de refugio para que Isa viva libre de los prejuicios de las normas de la sociedad de su época. Allí escribe, toca el violín y puede disfrutar, como madre, de su hija mestiza ( La Petite Fille Bois-Caïman», libro 2. ${ }^{\circ}, 12$ bis, 2010, p. 43).

Este texto resume un modo de vida que no es habitual. No sería extraordinario para un hombre de finales del siglo Xviı pero sí para una mujer. Isa se alojará, periódicamente, en esta cabaña y allí pasará los años más felices de su vida («La Petite fille de Bois Caïman», libro $2 .^{\circ}$, p. 15). Vivir en una pequeña cabaña aislada del mundo y en un lugar peligroso, rodeada de fieras, no parece un panorama muy atractivo para cualquier mujer, sobre todo si partimos de la idea admitida, pero no por ello cierta, de que las mujeres no saben vivir solas y que necesitan de la compañía y protección de un hombre. Sin embargo, Isa puede vivir en soledad; no solo porque tiene capacidad suficiente para sobrevivir en un medio hostil, sino porque tiene cualidades con las que poder disfrutar como son la música, ella toca el violín, o la pintura, que le permite dibujar el medio natural circundante con el objeto de ilustrar la enciclopedia que está escribiendo su amigo el naturalista Louis Murrait. Además, Isa sabe obtener el sustento en un medio natural y defenderse por sí misma de un posible ataque de animales o de transeúntes ya que es diestra en el manejo de las armas. Ella se ha sabido ganar el respeto del indio y del cazador que frecuenta estos parajes. Es en este lugar, alejado de la sociedad y libre de sus normas, donde Isa logrará, finalmente, ejercer de madre y compartir cierto tipo de experiencias con su hija que difícilmente podría tenerlas en un medio convencional. 
Esta cabaña es, en cierto modo, un símbolo feminista; representa la independencia de una mujer que ha adquirido la condición de sujeto en un mundo donde la costumbre es que la mujer sea un ser inmanente. Por ello Isa sufraga la construcción de la cabaña con el dinero que ha ganado trabajando («La Petite Fille de Bois-Caïman», libro 2. ${ }^{\circ}$, p. 27).

Es por el trabajo que la mujer ha franqueado, en gran parte, la distancia que la separaba del hombre; es solo el trabajo el que puede garantizar una libertad concreta. Desde que ella deja de ser un parásito, el sistema fundado sobre su dependencia se hunde; entre ella y el universo ya no hay necesidad de un mediador masculino. ${ }^{58}$

Esta necesidad de que la mujer tenga un trabajo expresada por Simone de Beauvoir parece que ya estaba en la mente de Isa. Cuando ella vivía en Santo Domingo trabajaba como secretaria en la plantación de Madame de Magnan; allí organizaba las labores agrícolas que efectuaban los esclavos, pero su trabajo le desagradaba porque se veía como una colaboradora en el mantenimiento de la esclavitud: «Yo me arreglaba con mi conciencia exigiendo que nuestros gestores trataran bien a los esclavos, pero no ignorando que ellos hacían lo que querían, en breve, yo me detesto» («La Petite Fille de Bois-Caïman», libro 1. ${ }^{\circ}$, p. 59). Luego, como hemos visto, trabajará como dibujante para el naturalista Louis de Marriat, que compagina con la labor de retratista para la burguesía de Luisiana. De todo ello obtendrá los ingresos suficientes para ser una mujer independiente.

\section{Conclusiones}

El concepto «feminismo» nació en el siglo XIX y se utilizó inicialmente para designar la patología de una enfermedad que producía la feminización de los varones. Luego, este término sirvió para denominar al movimiento para el reconocimiento de los derechos de igualdad entre hombres y mujeres. En la época en que se desarrolla Los pasajeros del viento, las reivindicaciones feministas eran impensables, «pero antes de que las palabras cristalicen las cosas, hay actos que las hacen nacer. Antes del feminismo, hubo mujeres que lucharon por la igualdad entre los sexos». ${ }^{59}$ Olympe de Gouges (1748-1793) o Mary Wollstonecraft (1759-1797) son contemporáneas de Isa que pertenecen a este grupo de mujeres que ayudaron a trazar el camino hacia la liberación de la mujer.

A su forma, Isa y Mary fueron feministas antes del feminismo; su moral es el resultado de su experiencia y el reflejo de la realidad femenina en su época.

En el siglo xviII, hubo mujeres que tuvieron un gran poder, pero siempre a través de un hombre. La más célebre es, quizás, Madame de Pompadour y sus armas fueron la seducción

\footnotetext{
${ }_{58}$ Beauvoir, S. (1976) Op. cit., p. 597.

59 Perrot, M. «Olympe de Gouges, Fora Tristan et George Sand: trois pionnières», en Le Magazine Littéraire, n. 566 (2016), p. 69.
} 
y la elocuencia. ${ }^{60}$ Estas mujeres influyentes no optaron por el honor sino por el deshonor que les confería más independencia.

Isa y Mary no podían disfrutar de las ventajas del honor, pues ello supondría el libre sometimiento a las normas de una sociedad patriarcal que convertía a la mujer en un ser pasivo. En cambio, el deshonor les ofrecía más ventajas que el honor: les daba la misma libertad que a los hombres.

Isa eligió libremente a su pareja; Mary se desprendió de la suya cuando la relación comenzó a deteriorarse; ambas fueron madres solteras; vivieron sin la tutoría de un padre que las dirigiera o de un esposo que les restringiera su libertad. Mary acabaría, probablemente, gestionando la fortuna familiar en Inglaterra. Isa trabajó como secretaria en una explotación agrícola, demostró tener talento para la escritura y hasta acabó ganándose la vida con la pintura; luchó por la abolición de la esclavitud y su elocuencia habría hecho que el doctor Paul Julius Moebius pusiera en duda su hipótesis sobre la inferioridad mental de la mujer.

Pero no podemos olvidar que Isa y Mary pertenecen a un mundo de ficción surgido de una mente masculina, la de François Bourgeon; como Isabel y Verena nacieron de la de Henry James.

Henry James se limitó a crear un tipo de mujer, con grandes cualidades, pero que sometida a un hombre acababa por ser anulada; su inteligencia será solo apariencia y su vida carecerá de trascendencia; la mujer solo puede realizarse a través del hombre por lo que su posición es siempre subordinada.

Isa y Mary no son seres creados para la sumisión al género masculino, sino para vivir en situación de igualdad. Mary explora su sensualidad y la comparte sin pedir nada a cambio, actúa instintivamente y vive como cree conveniente sin importarle las apariencias. Isa es inteligente e independiente, sus convicciones la llevan a luchar contra todas las formas de opresión y a soportar el peso de la injusticia más allá de lo exigible: es una idealista.

François Bourgeon puso mucho de sí mismo en los personajes de Los pasajeros del viento. ${ }^{61}$ Isa y Mary le sirven de caja de resonancia para transmitir la idea de que en épocas pasadas la mujer podía disfrutar de ciertos privilegios si luchaba por conseguirlos aunque, con frecuencia, esta aspiración entraba en conflicto con la moral impuesta a través de las leyes. Su discurso tiene hoy la misma validez que en el siglo XviII porque, si bien la situación de la mujer ha mejorado desde entonces en el mundo occidental, aún parte de la sociedad masculina se niega a aceptar los valores del feminismo o lo que es lo mismo: la igualdad de derechos entre el hombre y la mujer.

${ }^{60}$ Goncourt, E. \& Goncourt, J. Op. cit., pp. 371-405.

${ }^{61}$ Groensteen, T. «Entretien avec François Bourgeon», en Les Cabiers de la bande dessinée, no 65 (1985), p. 11. 


\section{BibLIOGRAFía}

Beauvoir, S. Le deuxième sexe. París, Gallimard, 1976.

Butler, J. El género en disputa. Barcelona, Paidós, 2007.

Cassagnes-Brouguet, S. \& Dousset-Seide, C. «Genre, normes et langages du costume», en Clio. Femmes, Genre, Histoire [En ligne], n. ${ }^{\circ} 36$ (2012), pp. 7-18.

Goncourt, E. \& Goncourt, J. La Femme au Dix-Huitième Siécle. París, G. Charpentier, Éditeur, 1882.

Groensteen, T. «Entretien avec François Bourgeon», en Les Cabiers de la bande dessinée, n. ${ }^{\circ} 85$ (1985), pp. 8-16.

James, H. Las bostonianas. Barcelona, Mondadori, 2006.

—Retrato de una dama. Barcelona, Thassàlia, 1997.

Mann, T. La montaña mágica. Barcelona, Edhasa, 2005.

- Las cabezas trocadas. Barcelona, Edhasa, 2002.

Moebius, J. P. La inferioridad mental de la mujer. Barcelona, Bruguera, 1982.

Mill, J. S. La esclavitud femenina. Edición en iBook. J. Borja, 2014.

Perrot, M. «Olympe de Gouges, Fora Tristan et George Sand: trois pionnières», en Le Magazine Littéraire, n. 566 (2016), pp. 69-70.

Pierpont, J. «Esclavage et condition feminine», en Les Cabiers de la bande dessinée n. ${ }^{\circ}$ 65 (1985), pp. 23-25.

Schwarzer, A. «"Das Ewig Weibliche ist eine Lüge”, Simone de Beauvoir im Gespräch mit Alice Schwarzer», en Der Spiegel, n. ${ }^{\circ} 15$ (1976). Edición en e-book.

Slosmanis, B. La morale féminine dans «Delphine» et «Corine» de Madame de Staël [tesis doctoral]. McGill University, Montreal, 1990. Disponible en http://digitool. library.mcgill.ca/webclient/StreamGate?folder id=0\&dvs=1495973179643 456

Thiebaut, M. Les chantiers d'une aventure. Tournai, Casterman, 1994.

-Le chemin de l'Atchafalaya. Tournai, 12bis, 2010.

Woolf, V. Un cuarto propio. Edición en iBook, Penguin Random House Grupo Editorial España, 2013. 